Bernadet is pedicure. Zij deelt haar praktijkervaringen - met een kwinkslag en in de overtreffende trap - middels deze column in Podopost en een blog in de nieuwsbrief. Daarbij ventileert zij haar ongezouten visie op zaken binnen de pedicurewereld.

\title{
Ga voor Goud!
}

"T $\mathrm{k}$ ben een fanatieke sportkijker. Lekker lui op de bank voor de buis kijken hoe anderen zich in het zweet werken. Dit jaar werden we op sportgebied ruim bedeeld met de olympische winterspelen in PyeongChang, het WK allround schaatsen, het WK voetballen, de Giro d'Italia, de Tour de France, de Vuelta in Spanje en niet te vergeten de Formule 1. Geweldig toch, die prestaties van onze topsporters! Onwillekeurig kijk ik altijd naar hun schoenen. Hoe zal het met die voeten gesteld zijn?

Neem nou de langebaanschaatsers. De binnenschoenen van hun schaatsen moeten zo strak mogelijk aan de voeten aansluiten. Dat zit dus behoorlijk krapjes. Kunnen ze hun tenen daarin nog wel bewegen? Tijdens de schaatsbewegingen wordt de hiel ver naar achteren in de schoen geduwd. Ik meen dat ze geen sokken dragen. Hoeveel blaren zullen ze per wedstrijd oplopen? Besteedt een deskundige aandacht aan die arme voeten? Zou een medisch pedicure sport met zo'n olympisch team meereizen? Commentatoren meten alles op tv breeduit, maar daarover hoor je niemand.

Dan de shorttrackers. Alsmaar dat schuin hangen in de bochten. Al die rondjes in dezelfde richting schaatsen. De voeten worden dan toch behoorlijk eenzijdig belast, ongeacht de topkwaliteit van de shorttrackschaatsen. Hoeveel problemen geeft dat bij de hallux? Zwikken hun enkels nooit door? Hoe verdragen de hielen van snowboarders op topniveau die gigantische klappen waarmee ze na driedubbele salto's weer op de sneeuw belanden? Ik zou vast beide enkels breken. Zijn hun snowboardschoenen voorzien van een speciaal schokabsorberend opvangsysteem of zoiets?

Olympisch kampioen zwemmen Maarten van der Weijden deed laatst een fantastische, bijna geslaagde poging om de elfstedentocht zwemmend af te leggen! Heb je zijn weke, witte, gerimpelde voeten op de brancard na afloop van die 55 uur in het water gezien? Welke consequenties heeft dat? Topsporters zullen vast en zeker goed voor hun lijf en dus ook hun voeten zorgen. Meer nog zullen topsporters altijd tot het gaatje gaan om die bovenste plek op het podium te bereiken, ook al betekent dat een aanslag op hun voeten. Prima dat onze beroepsgroep een steeds grotere rol speelt bij het geven van goede voetzorg aan onze

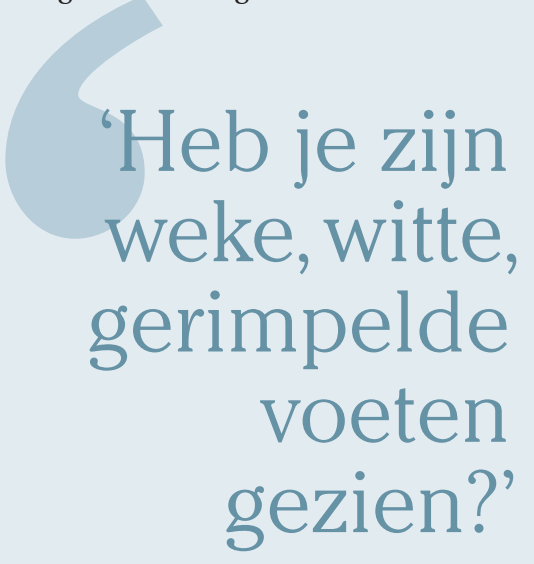

(top-)sporters. Zo bieden we hun letterlijk een belangrijke basis om succesvol te kunnen scoren.

Daarom, hup medisch pedicures sport, zet 'm op! Zet al je kennis en kunde in, eis je plek op in het speelveld, leg de lat voor jezelf hoog en presteer zo goed je kan. Haal die sporters binnen in je praktijk. Ga voor goud en het komt helemaal goed met sportend Nederland. 